\title{
SEXUAL DIMORPHISM IN FINGERPRINT PATTERN: A TOOL FOR SEX IDENTIFICATION.
}

\author{
Safaa M.George, Heba A. Yassa \\ Forensic and Clinical Toxicology Department, Faculty of Medicine, Assiut \\ University \\ Corresponding author: safaa Maher George.(safaa_georg@yahoo.com)
}

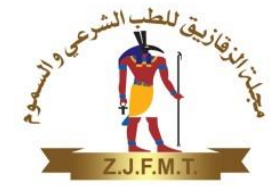

\begin{abstract}
Determination of individuality plays an important part of any medico-legal investigation. One of the most reliable methods of identification is fingerprints. The present study was conducted on 200 healthy adult Egyptian subjects in Assiut Governorate (100 males and 100 females) with age ranged from 18 to 60 years. Rolled impressions of the 10 digits from all participants and their print were recorded after taking their consent to determine the sexual dimorphism by fingertip pattern. Statistical analysis was made. The distribution analysis of fingerprint were (loops, whorls, arches and composite) and their subtypes. It was shown that loops are the most common, arches are the second and whorls the third, and composite are the least common with a very small percentage $(3.1 \%)$ in both hands. Most loops were ulnar while only $12.4 \%$ of loops were radial .Of the total arches, $86.5 \%$ arches were plain arches and $13.5 \%$ arches were tented arches. The frequency of the loops was higher in both right and left digits in males and females except the ring finger shows high frequency of whorls. The bimanual differences both in males and females are statistically significant for the occurrence of patterns on the digits of the right and left hands, but the difference between both sexes for the occurrence of patterns is not statistically significant.
\end{abstract}

Key words: print, fingerprint, dimorphism and identification

\section{I-INTRODUCTION}

D etermination of individuality is very important in forensic practice. Several parameters usually noted for the purpose of identification these include: race, age, gender, skin texture and features, speech and voice, gait pattern, tattoo marks, footprints, deformities, hair, scars, occupational marks, handwriting, garments and personal articles, fingerprints and DNA profile ( Hansi et al,2014). Out of all these parameters which is extensively used Fingerprints which is considered one of the cheapest, best, and legitimate proofs of identification, because they are permanent, individual and unique. (Pillay, 2009).

Dactylography or dactyloscopy is the study of fingerprints as a method of identification and is also known at present, as Henry-Galton system of Identification (Nandy, 2010). The word Dactylography is taken from two Greek words, daktylos meaning finger' and graphein meaning to write (Kumar, 2011). Fingerprints are formed in the human fetus before birth, and remain unchanged all over the life, unless damage or any lesion occurs to the dermal of the finger skin layer. Fingerprints are genotypically determined so they are unique to every single individual (Vij, 2005). It has been estimated that chances of two persons having identical finger impressions is a very rare chance (Modi, 2002). In spite of that the identical twins originating from one fertilized egg share the same DNA profile because they began existence as one entity, yet their fingerprints are characteristic as any unrelated persons (Mozayani, and Noziglia, 2006). The aim of this work was to examine the patterns of fingerprints in both hands as well as in individual digits of some Egyptian samples in Assiut Governorate, and to find if any variation occurs between both sexes for both hands.

\section{III-SUBJECTS AND METHODS}

In the present study, 200 persons were taken (100 males and 100 females). The age of subjects ranges from 18-60 years.

III a-Inclusion Criteria:

1-Belonging to Egyptian populations.

3-Healthy subjects. 
4-No deformity related to finger print (normal finger print).

\section{III b-Exclusion Criteria:}

1- Any type of physical deformity.

2- The subject with a major deformity (congenital/accidental) in the upper extremity (syndactyl, polydactyl).

3-Any trauma or previous surgery of finger that leads to change in the fingerprint pattern,

4- Any subject with gender identity disorder or with leprosy affecting fingers.

\section{III c-Methods:}

Fingerprints of the 10 digits are collected after washing the hands with soap and drying. The material used is ink pad. The fingers bulbs are rolled on the plate smeared with ink and then placed on a box of the white paper, with avoiding excessive pressure on the fingers while inking and recording (Nithin et. al, 2009), after the fingerprint is obtained the further details name, sex and age are noted. Digital prints were carefully examined to identify the following patterns, (using a hand lens: magnification 10x). Arches, loops, whorls, and composite based on the outward show of ridge lines delta and core.

\section{III d-Ethical Consideration:}

The approval for this study was obtained from the Ethical Clearance Committee of the faculty. Oral informed consent was obtained from all subjects after they were informed about the purpose and nature of the study.

\section{III e-Statistical methodology:}

The collected data subsequently entered in a database program. Descriptive statistical organized using SPSS (statistical Package for Social Science) version 20.Chi-square carried out on all cases to demonstrate test any significant gender difference; p-Value $<0.05$ was considered as significant.

\section{IV-RESULTS}

In the present study 200 persons were taken from out of which 100 males and 100 females, among males age group ranged from 18-60 years. Mean age group was $30.87+9.91$. In females, age group ranged from 18- 60 years. Mean age was $33.7+11.76$. Highest frequency of fingerprint patterns in both hands were mostly loops $(36.3 \%)$ followed by arches $(31.8 \%)$, and whorls (28.8\%) (Table1).

Gender wise distribution of fingerprint pattern of the male and female hands (in both hands):

In the male population, frequency were found to be loops (40\%) followed by arches $(35 \%)$ and whorls $(22.4 \%)$. In the females frequency were found to be whorls $(35.2 \%)$ followed by loops $(32.6 \%)$ and arches $(28.6 \%)$. Least noted pattern among both was composite (Table2).

Subtypes of each of the four fingerprint pattern were identified and their distribution was given below:

-Loops: In both males and females, ulnar loops were the commonest type and radial loops were the least common. (Table3).

-Whorls: In both males and females, Spiral whorls were the predominant type and Elliptical whorls were the least common one. (Table4).

-Arches: In both males and females, Plain arches were the most common, tented arches were the least common one. (Table 5).

-Composites: In both males and females the most common type of composite pattern was twinned loop and the least common was central pocket. (Table 6).

The predominant pattern among both males and females was ulnar loop (33.6\%) in male and $(30 \%)$ in female, followed by plain arches $(30 \%)$ in males and $(25 \%)$ in females respectively. Central pocket loop whorl in male was $(0.02 \%)$ and in females was $(0.06 \%)$ respectively. It has been observed that whorls are more abundant than loops in females. The difference was insignificant ( $p>0.05) \quad$ [Table7]. Fingerprint pattern in every digit (on different digits separately:

The frequency of the ulnar loops was higher in both right and left digits in males and females except the ring finger had higher frequency of whorls. Whorls were highly frequent on the, ring, thumb, and middle in that order and they were least on the little fingers in male and female subjects. 
A high frequency of arches on the right hands except on the ring finger in females while, males presented a high frequency of arches on the left hands except on the ring finger and there was a bimanual difference in the distribution of the arches was significant in both sexes . Composites were highly frequent in thumb finger in both sexes. The difference was significant $(\mathrm{p}<0.05)$. [Table 8,9$]$.

Table (1): Distribution of different patterns of fingerprints in both hands

\begin{tabular}{|c|c|c|}
\hline Pattern & Cases & $\%$ \\
\hline Loops & 726 & 36.3 \\
\hline Arches & 636 & 31.8 \\
\hline Whorls & 576 & 28.8 \\
\hline Composites & 62 & 3.1 \\
\hline Total & 2000 & 100 \\
\hline
\end{tabular}

Table (2): Fingerprint patterns and gender distribution in both hands.

\begin{tabular}{|c|c|c|c|c|c|}
\hline \multirow{2}{*}{ Pattern } & \multicolumn{2}{|c|}{ Males } & \multicolumn{2}{c|}{ Females } & \multirow{2}{*}{ Total } \\
\cline { 2 - 5 } & No & $\%$ & No & $\%$ & \\
\hline Loops & 400 & 40 & 326 & 32.6 & 726 \\
\hline Arches & 350 & 35 & 286 & 28.6 & 636 \\
\hline Whorls & 224 & 22.4 & 352 & 35.2 & 576 \\
\hline Composites & 26 & 2.6 & 36 & 3.6 & 62 \\
\hline Total & 1000 & 100 & 1000 & 100 & 2000 \\
\hline
\end{tabular}

Table (3): Types of loop pattern and gender distribution.

\begin{tabular}{|c|c|c|c|}
\hline \multirow{2}{*}{ Types of loops } & Males & Females & Total \\
& & & $636(87.6 \%)$ \\
\hline Ulnar & $336(84 \%)$ & $300(88.2 \%)$ & $90(12.4 \%)$ \\
\hline Radial & $64(16 \%)$ & $26(11.8 \%)$ & $726(100 \%)$ \\
\hline Total & $400(100 \%)$ & $326(100 \%)$ & \\
\hline
\end{tabular}

Table (4): Types of whorl pattern and gender distribution.

\begin{tabular}{|c|c|c|c|}
\hline $\begin{array}{c}\text { Types of } \\
\text { Whorls }\end{array}$ & Males & Females & Total \\
\hline Spiral & $133(59.4 \%)$ & $218(61.9 \%)$ & $351(60.9 \%)$ \\
\hline Circular & $62(27.7 \%)$ & $90(25.6 \%)$ & $152((26.4 \%)$ \\
\hline Double core & $22(9.8 \%)$ & $29(8.2 \%)$ & $51(8.9 \%)$ \\
\hline Elliptical & $7(3.1 \%)$ & $15(4.3 \%)$ & $22(3.8 \%)$ \\
\hline Total & $224(\%)$ & $352(100 \%)$ & $576(100 \%)$ \\
\hline
\end{tabular}


Table (5): Types of arch pattern and gender distribution.

\begin{tabular}{|c|c|l|l|}
\hline Types of Arches & Males & Females & Total \\
\hline Plain & $300(85.7 \%)$ & $250(87.4 \%)$ & $550(86.5 \%)$ \\
\hline Tented & $50(14.3 \%)$ & $36(12.6 \%)$ & $86(13.5 \%)$ \\
\hline Total & $350(100 \%)$ & $286(100 \%)$ & $636(100 \%)$ \\
\hline
\end{tabular}

Table (6): Types of composite pattern and gender distribution.

\begin{tabular}{|c|c|c|c|}
\hline Types of composites & Males & Females & Total \\
\hline Twinned loops & $10(38.5 \%)$ & $15(41.6 \%)$ & $25(40.3 \%)$ \\
\hline Lateral pocket loops & $8(30.8 \%)$ & $10(27.8 \%)$ & $18(29.1 \%)$ \\
\hline Accidental & $6(23.1 \%)$ & $5(13.9 \%)$ & $11(17.7 \%)$ \\
\hline Central pocket loops & $2(7.6 \%)$ & $6(16.7 \%)$ & $8(12.9 \%)$ \\
\hline Total & $26(100 \%)$ & $36(100 \%)$ & $62(100 \%)$ \\
\hline
\end{tabular}

Table (7): Frequencies of fingerprint patterns among males and females in both hands by Chi-square test.

\begin{tabular}{|c|c|c|c|c|c|c|}
\hline \multirow[t]{2}{*}{ Pattern } & \multicolumn{2}{|c|}{ Male } & \multicolumn{2}{|c|}{ Female } & \multirow[t]{2}{*}{ Total } & \multirow{2}{*}{$\begin{array}{c}{ }^{* p}- \\
\text { value }\end{array}$} \\
\hline & Frequency & Percentage & Frequency & Percentage & & \\
\hline Ulnar (loops) & 336 & $33.6 \%$ & 300 & $30 \%$ & 636 & $>0.05$ \\
\hline Plain (arches) & 300 & $30 \%$ & 250 & $25 \%$ & 550 & $>0.05$ \\
\hline Spiral (whorls) & 133 & $13.3 \%$ & 218 & $21.8 \%$ & 351 & $>0.05$ \\
\hline Circular (whorls) & 62 & $6.2 \%$ & 90 & $9 \%$ & 152 & $>0.05$ \\
\hline Radial (loops) & 64 & $6.4 \%$ & 26 & $2.6 \%$ & 90 & $>0.05$ \\
\hline Tented (arches) & 50 & $5 \%$ & 36 & $3.6 \%$ & 86 & $>0.05$ \\
\hline Double core (whorls) & 22 & $2.2 \%$ & 29 & $2.9 \%$ & 51 & $>0.05$ \\
\hline Twinned loops (composites) & 10 & $1 \%$ & 15 & $1.5 \%$ & 25 & $>0.05$ \\
\hline $\begin{array}{c}\begin{array}{c}\text { Elliptical } \\
\text { (whorls) }\end{array} \\
\end{array}$ & 7 & $0.07 \%$ & 15 & $1.5 \%$ & 22 & $>0.05$ \\
\hline $\begin{array}{l}\text { Lateral pocket loops } \\
\text { (composites) }\end{array}$ & 8 & $0.08 \%$ & 10 & $1 \%$ & 18 & $>0.05$ \\
\hline Accidental (composites) & 6 & $0.06 \%$ & 5 & $0.05 \%$ & 11 & $>0.05$ \\
\hline $\begin{array}{c}\text { Central pocket loops } \\
\text { (composites) }\end{array}$ & 2 & $0.02 \%$ & 6 & $0.06 \%$ & 8 & $>0.05$ \\
\hline Total & $* * 1000$ & 100 & 1000 & 100 & & 00 \\
\hline
\end{tabular}

NB: *p-value $>0.05$ is insignificant; The number of cases was 200 cases (100 male, 100 female); **100 casex 10 digit $=1000$ 
Table (8): Frequencies of fingerprint patterns in different digits in males by Chi-square test.

\begin{tabular}{|c|c|c|c|c|c|c|c|c|c|c|c|}
\hline \multirow[t]{2}{*}{ Pattern } & \multicolumn{2}{|c|}{ Little finger } & \multicolumn{2}{|c|}{ Ring finger } & \multicolumn{2}{|c|}{ Middle finger } & \multicolumn{2}{|c|}{ Index finger } & \multicolumn{2}{|c|}{ Thumb } & \multirow{2}{*}{$\begin{array}{c}* \mathrm{p}- \\
\text { value }\end{array}$} \\
\hline & RH & LH & RH & LH & RH & LH & RH & LH & RH & LH & \\
\hline Ulnar (loops) & 34 & 30 & 15 & 12 & 40 & 23 & 25 & 21 & 20 & 27 & $<0.05$ \\
\hline Radial (loops) & 2 & 2 & 2 & 0 & 4 & 0 & 0 & 4 & 2 & 0 & $<0.05$ \\
\hline Plain (arch) & 2 & 8 & 7 & 3 & 0 & 0.75 & 1 & 3 & 0 & 0 & $<0.05$ \\
\hline Tented (arches) & 0 & 0 & 0.13 & 0 & 0 & 0 & 0 & 3 & 0.12 & 0.66 & $<0.05$ \\
\hline Spiral (whorls) & 0.3 & 13 & 20 & 30 & 13 & 10 & 15 & 10 & 10 & 15 & $<0.05$ \\
\hline Circular (whorls) & 0 & 0.2 & 0 & 2 & 3 & 0 & 0 & 0 & 1 & 0 & $<0.05$ \\
\hline Double core (whorls) & 0 & 0 & 2 & 0.3 & 0 & 0 & 0 & 0 & 0 & 0 & $<0.05$ \\
\hline Ellipticl (whorls) & 0 & 0 & 0.7 & 0 & 0 & 0 & 0 & 0 & 0 & 0 & $<0.05$ \\
\hline $\begin{array}{l}\text { Twinned loops } \\
\text { (composite) }\end{array}$ & 1 & 2 & 4 & 0 & 3.13 & 0 & 10 & 0 & 10 & 10 & $<0.05$ \\
\hline $\begin{array}{l}\text { Lateral pocket loops } \\
\text { (composite) }\end{array}$ & 5 & 0 & 0.8 & 0 & 1.56 & 0 & 0 & 0.87 & 2.66 & 0 & $<0.05$ \\
\hline $\begin{array}{l}\text { Accidental } \\
\text { (composite) }\end{array}$ & 0.5 & 0 & 0.2 & 0 & 1.56 & 0 & 0 & 5.57 & 0 & 0 & $<0.05$ \\
\hline $\begin{array}{c}\text { Central pocket loops } \\
\text { (composite) }\end{array}$ & 0 & 0 & 0 & 0.87 & 0 & 0 & 0.56 & 1 & 1.56 & 0 & $<0.05$ \\
\hline Total & & & & & & & & & & & \\
\hline
\end{tabular}

$*$ p-value $<0.05$ is significant

Table (9): Percentage distribution of patterns in different digits in females by Chi-square test.

\begin{tabular}{|c|c|c|c|c|c|c|c|c|c|c|c|}
\hline \multirow[t]{2}{*}{ Pattern } & \multicolumn{2}{|c|}{ Little finger } & \multicolumn{2}{|c|}{$\begin{array}{l}\text { Ring } \\
\text { finger }\end{array}$} & \multicolumn{2}{|c|}{ Middle finger } & \multicolumn{2}{|c|}{ Index finger } & \multicolumn{2}{|c|}{ Thumb } & \multirow{2}{*}{$\begin{array}{c}\text { p-value } \\
<0.05\end{array}$} \\
\hline & RH & $\mathrm{LH}$ & RH & $\mathrm{LH}$ & $\mathrm{RH}$ & LH & RH & $\mathrm{LH}$ & RH & $\mathrm{LH}$ & \\
\hline $\begin{array}{l}\text { Ulnar } \\
\text { (loops) }\end{array}$ & 40 & 30 & 20 & 15 & 30 & 29 & 20 & 19 & 25 & 20 & $<0.05$ \\
\hline Radial (loops) & 0.87 & 2 & 1 & 1 & 0 & 1 & 1 & 2 & 0 & 0.71 & $<0.05$ \\
\hline Plain (arches) & 5 & 4 & 5 & 10 & 1 & 0.45 & 3 & 4 & 0.71 & 0 & $<0.05$ \\
\hline $\begin{array}{c}\text { Tented } \\
\text { (arches) }\end{array}$ & 0.45 & 1 & 1 & 1 & 0 & 0 & 4 & 2 & 0 & 0 & $<0.05$ \\
\hline Spiral (whorls) & 6 & 5 & 30 & 15 & 8 & 7 & 12 & 12 & 14 & 14 & $<0.05$ \\
\hline Circular (whorls) & 0 & 0 & 0 & 0 & 2 & 1 & 0 & 1 & 0 & 1 & $<0.05$ \\
\hline Double core (whorl) & 0 & 0 & 0 & 0 & 1 & 0 & 2 & 1 & 1 & 1 & $<0.05$ \\
\hline Elliptical (whorsl) & 0 & 0 & 0 & 0 & 3 & 2 & 2 & 0 & 0 & 1 & $<0.05$ \\
\hline $\begin{array}{c}\text { Lateral pocket loop } \\
\text { (composites) }\end{array}$ & 1 & 0.45 & 0 & 0 & 1 & 0.25 & 0 & 1 & 2 & 3 & $<0.05$ \\
\hline $\begin{array}{l}\text { Twinned loop } \\
\text { (composites) }\end{array}$ & 0 & 0 & 2 & 2 & 5 & 2 & 3 & 2 & 9 & 3 & $<0.05$ \\
\hline $\begin{array}{l}\text { Accidental } \\
\text { (composites) }\end{array}$ & 2 & 1 & 0.71 & 0 & 3 & 1.3 & 2 & 2 & 1.12 & 2.6 & $<0.05$ \\
\hline $\begin{array}{c}\text { Central pocket loop } \\
\text { (composites) }\end{array}$ & 0 & 0.71 & 0 & 0 & 1 & 1 & 2 & 3 & 1 & 0.4 & $<0.05$ \\
\hline Total & & & & & & & & & & 10 & \\
\hline
\end{tabular}

$* \mathrm{p}$-value $<0.05$ is significant 


\section{V-DISCUSSION}

Fingerprints are formed in the human fetus before birth and they are unique to every single individual and fixed does .They don't change throughout life unless damage occurs to the dermis of the finger (Han et al., 2004). The aim of this work was to study various patterns of fingerprints and their distribution in different fingers, and to find if any variation occurs between both sexes for both hands.

In this study, the majority of the patterns observed were loops followed by arches and whorls in the both hands. The least frequently observed pattern in the total population was composites. On analyzing the distribution of fingerprint patterns in either sex, loops were the predominant pattern, followed by arches in males, the third most common pattern was whorls, followed by composites. While in females, the most common pattern was whorls followed by loops then arches.

Owing to the detailed classification and the subtypes used in this study the results of this study vary slightly against most of the other researchers who used general major classification (i.e. loops, arches and whorls). The results of the study are in partial accordance with the other studies who also found that the loop pattern is the most common type in the various populations as Gangadhar and Rajashekara. (1993) ,who reported predominance of loop patterns $(57.11 \%)$ followed by whorls (27.89\%) and arches (15\%) in Adikarnataka population of Mysore city of Karnataka State also Igbigbi and Msamati in their study on indigenous black Zimbabweans, in Kenyan and Tanzanian subjects (2002) found that ulnar loops were the most prevalent digital pattern type in most sexes, followed by whorls in males and arches in females, Another study conducted on males of Mundas and Lodhas tribals from Midnapur district in West Bengal by Purkait,(2003) who studied the frequency and variation of fingerprint patterns in the 10 digit classification mentioned that Mundas have higher incidence of whorl and loop patterns whereas the loops were more frequent among Lodhas. Another study by Jaga and Igbigbi in
Ijaw subjects of Southern Nigerians (2008), Nithin et. al.(2009) who reported the most common occurrence of ulnar loops $(52.3 \%)$ followed by whorl pattern (28.74\%) in South Indians of Mysore and by Eboh (2012) who reported that the most common types are ulnar loop followed by whorls and arches patterns, in Anioma and Urhobo population of Southern Nigeria .

The results of the current study are found to be in contrast to some researchers who reported whorls to be the most common pattern, followed by loops and arches in both the hands of both genders as Ching Cho(1998) who reported the predominance of whorls $(60.6 \%)$ followed by ulnar loops (38.65\%) in New Zealand Samoans, and by Singh and Garg.(2004) in Rajputs of Himachal Pradesh, by Banik et. al.(2009) among Rengma Nagas of Nagaland, by Biswas(2011) among Dhimals of North Bengal .These differences may be explained by the developmental variation and heritability among sexes that may account for sexual dimorphism of these patterns. Arches were present more in males than in females in this study. This is contrary to the study of various other authors (Ekanem et al., 2009, Prateek and Keerthi 2010, Eboh ,2012, )

The study of fingerprint patterns on individual digits revealed that there was preponderance of loops on the all fingers except ring finger, whorls on the ring, thumb and index finger and arches on the little and ring fingers in both hands.

Also, the results of this study are found to be in contrast to the studies conducted by Amit and Anjulika. who study the fingerprint patterns among medical students in vidarbha region (2015) in India and observed that the higher majority of loops were present in little and middle finger of both genders and also the ring finger in males showed maximum percentage of whorls, while in little and ring fingers of both genders arches were more which is in accordance with kanchan and Chattopadhyay (2006) , who studied the fingerprint patterns distribution among medical students. The differences in the results of this study from 
other studies may be due to regional differences.

\section{VI-CONCLUSION}

In this study, distribution of fingerprints patterns as well as their subtypes was made out. Ulnar loops were the most common type of patterns followed by plain arches in both males and females. However, in both genders the frequency of whorl pattern is greater in ring finger. Central pocket loop (subtype of composites) were the least common type in male; accidental (subtype of composites) also was the least common type in females. The bimanual differences both in males and females are statistically significant for the occurrence of patterns on the digits of the right and left hands, but the difference between both sexes for the occurrence of patterns is not statistically significant. Further studies on larger sample sizes are needed to substantiate our findings.

\section{VII-Funding}

None.

\section{VIII-Conflict of interest}

None.

\section{IX-Acknowledgment}

The authors are sincerely thankful to all the individuals who donated their prints for the study.

\section{REFERENCES}

1. Amit, A.M., and Anjulika, A.M. (2015): Study of fingerprint patterns among medical students in vidarbha region India. International journal of anatomy and research.; 3(2):1043-45.

2. Banik, S.D., Pal, P., Mukherjee, D.P. (2009): Finger dermatoglyphic variations in Rengma Nagas of Nagaland India. Coll Antropol.; 32 (1):31-35.

3. Biwas, S. (2011): Finger and palmer dermatoglypic study among the Dhimals North Bengal, India Journal of Anthropologist. 13(3):235- 238

4. Ching Cho. (1998): A finger dermatoglyphics of the new Zealand-Samoans. Korean J Bio Sci. 2:507-11.

5. Eboh, DEO. :( 2012): Digital Dermatoglyphic Patterns of Anioma and Urhobo Students in Two tertiary Institutions of Delta State,
Southern Nigeria. Journal of Medicine and Biomedical Research. 11(2): 90-96. 19.

6. Ekanem, E.P. ,Ehwa, M.A., Udoaffah, G.U., Ekanem, T.B., Akpantah, A.O. (2009): Digital Dermatoglyphic Patterns of Annang Ethnic Group In Akwa Ibom State Of Nigeria. The Internet Journal of Biological Anthropology. Volume 3(1).

7. Gangadhar, M.R., and Rajashekara, R.K. (1993): Finger dermatoglyphics of Adikarnatakas: a scheduled caste population of Mysore City, Karnataka.Man India. 83(1\&2):183-93.

8. Han, Y., Ryu, C., Moon, J., Kim, H., Choi, H.(2004): A Study on Evaluating the Uniqueness of Fingerprints Using Statistical Analysis. Information Security and Cryptology-ICISC; -05: 467-477.

9. Hansi, D. B., Ashish, D.B,Neeti, S.K.( 2014): Distribution of Fingerprint Patterns in an Indian Population. Malaysian Journal of Forensic Sciences 5(2):18-21

10. Iaga, B.N. and Igbigbi, P.S. (2008): Digital and palmar dermatolyphics of the Ijaw of southern Nigeria .Afr J Med Med Sci .37 (1) $: 1-5$.

11. Igbigbi, P.S, and Msamati, B.C. (2002): Palmar and digital dermatoglyphics of indigenous black Zimbabweans.Med Sci Monit.; 8(II):757761.

12. Kanchan, T., and Chattopadhyay, S.( 2006) :Distribution of fingerprint patterns among medical students. JIAFM.; 28(2): 23-9.

13. Kumar, A. (2011): Textbook of Forensic Medicine, Medical Jurisprudence and Toxicology). 1st ed. Avichal Publishing Company; 4-5.

14. Modi, JP. (2002): Modis medical jurisprudence and toxicology.22 ${ }^{\text {nd }}$ ed.Nodia:Lexis Nexis Butterworths;pp37,39,40,72.

15. Mozayani, A. and Noziglia, C. (2006): The laboratory hand book-procedures and practice. 1st ed..Totowa.New Jeresy:Humana Press: pp123

16. Nandy, A. (2010): Identification of an individual. In: Principles of forensic medicine. 3nd ed. (Reprint), Calcutta: New Central Book Agency (P) Ltd.; 158-163.

17. Nithin, M.D, Balaraj, B.M, Manjunatha, B, Shashidhar, C.M. (2009): Study of fingerprint classification and their gender distribution 
among South Indian population. J Forensic Leg Med.16(8):460-3

18. Pillay, VV. (2009): Textbook of Forensic Medicine and Toxicology. 15th ed. Hyderabad: Paras Medical Publishers53-94

19. Prateek, R and, Keerthi, R .P. (2010): A study of fingerprints in relation to gender and blood group. JIAFM; 32 (1): 11- 14.
20. Purkait, R. (2003): Fingerprint classification: A comparative study among Mindas and Lodhas. JMFT 14(1):31-32.

21. Singh, I. and Garg R.K. (2004). Finger Dermatoglyphics: A study of the Rajputs of Himachal Pradesh. Anthropologist.6 (2): 155156.

22. Vij, K. (2005): Textbook of Forensic Medicine and Toxicology. 3rd ed. New Delhi: Elsevier. 
التمييز الجنسي في نمط بصمات الأصابع: أداة لتحديد الجنس.

\section{هبة عطية يسي ، صفاء ماهر جورج}

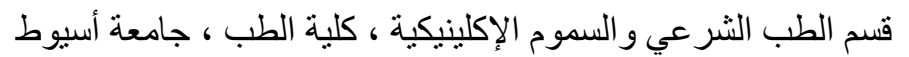

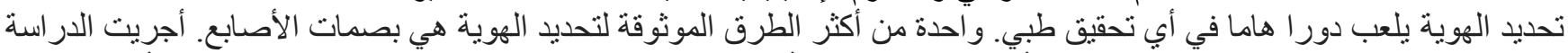

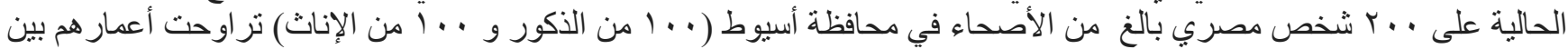

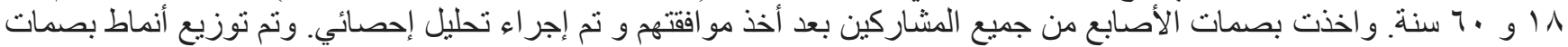

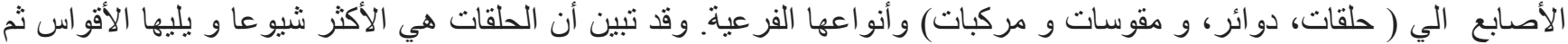

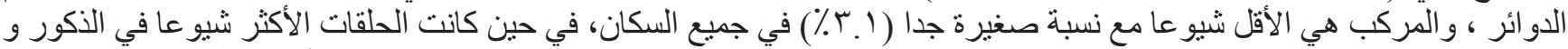

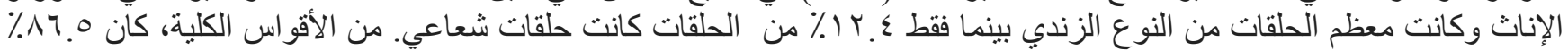

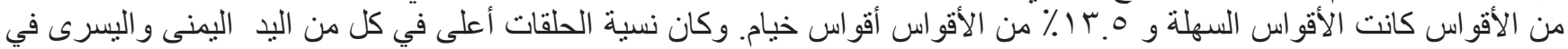

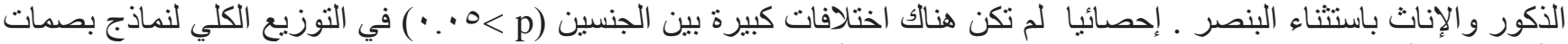

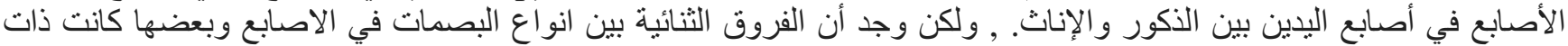

